\title{
Temporal and spatial variation of Myriapoda (Diplopoda and Chilopoda) assemblages in a Neotropical floodplain
}

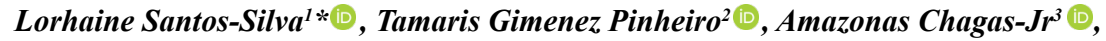 \\ Marinêz Isaac Marques ${ }^{3}$ \& Leandro Dênis Battirola ${ }^{1}$ (i) \\ ${ }^{1}$ Universidade Federal de Mato Grosso, Instituto de Ciências Naturais, Humanas e Sociais, Programa \\ de Pós-Graduação em Ciências Ambientais, Av. Alexandre Ferronato 1.200, Setor Industrial, 78557-267, \\ Sinop, MT, Brasil \\ ${ }^{2}$ Universidade Federal do Piauí, Avenida Cícero Eduardo, s/n, Junco, 64607-675, Picos, PI, Brasil \\ ${ }^{3}$ Universidade Federal de Mato Grosso, Instituto de Biociencias, Departamento de Biologia e Zoologia, \\ Avenida Fernando Corrêa da Costa 2.367, Boa Esperança, 78060-900, Cuiabá, MT, Brasil \\ *Corresponding author: Lorhaine Santos-Silva, e-mail: lorhaine.silva@gmail.com
}

SANTOS-SILVA, L., PINHEIRO, T.G., CHAGAS-JR, A., MARQUES, M.I., BATTIROLA, L.D. Temporal and spatial variation of Myriapoda (Diplopoda and Chilopoda) assemblages in a Neotropical floodplain. Biota Neotropica 18(2): e20180514. http://dx.doi.org/10.1590/1676-0611-BN-2018-0514

\begin{abstract}
Myriapods constitute important edaphic macrofauna taxa which dwell in different trophic levels and influence the dynamics of these environments. This study evaluated the variation in composition, richness and abundance of edaphic myriapod assemblages as a function of the distribution and structure of flooded and nonflooded habitats (spatial variation) and hydrological seasonality (temporal variation) in a floodplain of the northern Pantanal region of Mato Grosso, Brazil. Sampling was carried out in three areas of the Poconé Pantanal, along an altitudinal and inundation gradient consisting of inundated and non-inundated habitats and different vegetation formations. Three quadrats $(10 \times 10 \mathrm{~m})$ were delimited within each habitat type, where sampling was performed using pitfall traps and mini-Winkler extractors during the dry, rising water, high water and receding water periods of two hydrological cycles within the Pantanal (2010/2011 and 2011/2012). A total of 549 millipedes were collected, consisting of 407 Diplopoda and 142 Chilopoda distributed in six orders, 12 families and 20 species. The assemblages composition varied throughout the seasonal periods, indicating that the rising water and dry periods differed from the high water and receding water periods. In addition to the variation between seasonal periods, myriapod richness and abundance also varied in relation to areas consisting of different vegetation formations. Thus, it can be concluded that the hydrological seasonality associated with the inundation gradient and different vegetation types were determinant in the heterogeneous spatial and temporal distribution of myriapod assemblages, validating that the conservation of these invertebrates in the Pantanal is directly linked to the preservation of vegetation, and consequently, ecosystem integrity.
\end{abstract}

Keywords: Biodiversity, conservation, myriapods, seasonality, wetlands.

\section{Variação temporal e espacial da assembleia de Myriapoda (Diplopoda e Chilopoda) em uma planície de inundação Neotropical}

Resumo: Os miriápodes constituem importantes táxons da macrofauna edáfica atuando em diferentes níveis tróficos, influenciando a dinâmica desses ambientes. Este estudo avaliou a variação na composição, riqueza e abundância da assembleia de miriápodes edáficos em função da distribuição e estrutura de habitats inundáveis e não inundáveis (variação espacial) e da sazonalidade hidrológica (variação temporal) em uma planície de inundação na região norte do Pantanal de Mato Grosso, Brasil. As amostragens foram realizadas em três áreas no Pantanal de Poconé, em um gradiente altitudinal e de inundação, constituídas por habitats inundáveis e não inundáveis e por diferentes formações vegetacionais. Em cada tipo de habitat foram delimitados três quadrantes $(10 \times 10 \mathrm{~m})$, onde foram efetuadas amostragens com armadilhas pitfall e Extrator mini-Winkler, ao longo dos períodos de seca, enchente, cheia e vazante, durante dois ciclos hidrológicos do Pantanal (2010/2011 e 2011/2012). Foram amostrados 549 
miriápodes, dos quais 407 Diplopoda e 142 Chilopoda, distribuídos em seis ordens, 12 famílias e 20 espécies. A composição da assembleia variou ao longo dos períodos sazonais, indicando que a enchente e seca diferem da cheia e vazante. Além da variação entre os períodos sazonais, a riqueza e abundância de miriápodes variaram também em relação às áreas, constituídas por diferentes formações vegetacionais. Assim, pode-se concluir que a sazonalidade hidrológica associada ao gradiente de inundação e os diferentes tipos vegetacionais foram determinantes para a distribuição espacial e temporal heterogênea da assembleia de miriápodes, evidenciando que a conservação destes invertebrados no Pantanal está diretamente ligada à preservação da vegetação e, consequentemente, de sua integridade ecossistêmica.

Palavras-chave: Áreas úmidas, biodiversidade, conservação, miriápodes, sazonalidade.

\section{Introduction}

The distribution patterns in the richness and diversity of animal species in tropical environments are strongly related to the richness, composition and structure of plant communities. Heterogeneous environments possessing greater vegetation complexity associated with seasonal abiotic variations generally provide a greater variety of resources and niches for fauna (e.g. Ferreira \& Casatti 2006, Lopes et al. 2011, Miranda et al. 2013), factors considered determinant for the coexistence of species (Tews et al. 2004, Freitas et al. 2006, Giacomini 2007).

Like other wetlands, the Pantanal of Mato Grosso is considered a spatially and temporally complex ecosystem (Heckman 1998). The temporal variation in water level is one of its main characteristics, making periodic flooding a determinant in its ecological processes (Junk 1993, Junk \& Nunes-da-Cunha 2005, Junk et al. 2015). The local differences in flood intensity and duration, as well as the characteristic topographic variations of the Pantanal, shape the landscape and, consequently, the distribution of the phytophysiognomic units, forming a mosaic of habitats (Silva et al. 2000, Rebellato \& Nunes-da-Cunha 2005, Nunes-da-Cunha et al. 2007, Fantin-Cruz et al. 2010, Machado et al. 2012) consisting of forests, fields, and monodominant patches (Arieira \& Nunes-da-Cunha 2006, Nunes-da-Cunha \& Junk 2011, 2015). This variety of habitats is responsible for maintaining rich and abundant fauna (Junk et al. 2006, Alho \& Sabino 2011), including rarely studied taxa such as the arthropod group Myriapoda (Golovatch et al. 2005, Battirola et al. 2009, 2017c).

Although they play a vital role in the dynamics of ecosystems and represent an important part of edaphic macrofauna, Myriapoda constitute a group that has been the subject of little studies in relation to its diversity and ecology (Golovatch et al. 1995, Adis \& Harvey 2000, Brewer et al. 2012). Among Myriapoda, Chilopoda and Diplopoda are the most abundant and species rich classes. Chilopoda comprises five orders and approximately 3,300 species. They are exclusively predators and, in most cases, feed on other arthropods and small vertebrates proportional to their size (Edgecombe \& Giribet 2007, Noronha et al. 2015, Guizze et al. 2016). Diplopoda are distributed in approximately 16 orders with 140 families and more than 11,000 species (Enghoff et al. 2015). They are detritivores, participating in the decomposition, reduction and fragmentation of organic material (Golovatch et al. 1995, Hoffman et al. 2002, Battirola et al. 2011, Minelli \& Golovatch 2013).

In seasonally flooded areas, stress derived from inundation causes myriapods to develop specific survival strategies (Adis 1997). In the Pantanal of Mato Grosso, adaptations and survival strategies are known for the diplopods Plusioporus salvadorii Silvestri, 1895 (Spirostreptidae) and Pantanalodesmus marinezae Hoffman, 2000
(Chelodesmidae), terrestrial species that migrate to the trunks of trees during flooding, where they remain until the end of the inundation period (Adis et al. 2001), Poratia salvator Golovatch \& Sierwald, 2000 (Pyrgodesmidae) and Promestosoma boggianii (Silvestri, 1898) (Paradoxosomatidae), both of which synchronize their life cycles and phenology to that of the region's flood cycles (Pinheiro et al. 2009, 2011, Wantzen et al. 2016, Battirola et al. 2017c, Santos-Silva et al. 2018), and also Polyxenida, which has a distribution pattern between soil and tree canopy influenced by seasonal variations (Battirola et al. 2009).

Considering the importance of studies on biodiversity and its maintenance mechanisms, as well as the relationship between species and their habitats, particularly in priority conservation areas such as the Pantanal of Mato Grosso, this study aimed to: (i) evaluate the composition of Myriapoda assemblages (Chilopoda and Diplopoda) in a floodplain of the northern Pantanal of Mato Grosso; and (ii) to analyze the influence of habitat structure (flooded and non-flooded) and seasonality on the abundance and richness of myriapods, thus contributing to the knowledge of distribution patterns of these taxa in wetlands.

\section{Material and Methods}

\section{Study Area}

Sampling was performed in inundated (I) and non-inundated (NI) habitats in three sample areas (A1, A2, A3), distributed across an altitudinal and inundation gradient along the Porto Cercado road, located between the Bento Gomes and Cuiabá rivers, in the Poconé Pantanal, Mato Grosso, Brazil (16²0'56"S 056 29'69"W and 16²9'82"S $056^{\circ} 23^{\prime} 95^{\prime \prime} \mathrm{W}$ ) (Figure 1). The local climate is classified as tropical savannah AW under the Köppen Classification system, characterized by dry winters and rainy summers, with temperature ranging between 22 and $32^{\circ} \mathrm{C}$ (Hasenack et al. 2003). Annual rainfall ranges from 1,000 to $1,500 \mathrm{~mm}$, with rainfall below $10 \mathrm{~mm}$ occurring during the dry season (Radambrasil 1982). Sampling occurred throughout the four seasonal periods typical of the region; dry (July to September), rising water (October to December), high water (January to March) and receding water (April to June) during two annual cycles (2010/2011 and 2011/2012), characterized according to Heckman (1998).

Area A1 represents a higher elevation with low flood amplitude $(0.1$ $\mathrm{m}$ of depth), and is located next to the Bento Gomes River; area A2 is located at a mid-point along the gradient, with intermediate elevation and flood amplitude ( $0.25 \mathrm{~m}$ depth); area A3 is located near the Cuiabá River, and is the area with least elevation and therefore susceptible to a greater flood amplitude ( $0.5 \mathrm{~m}$ depth) (Figure 1$)$. 

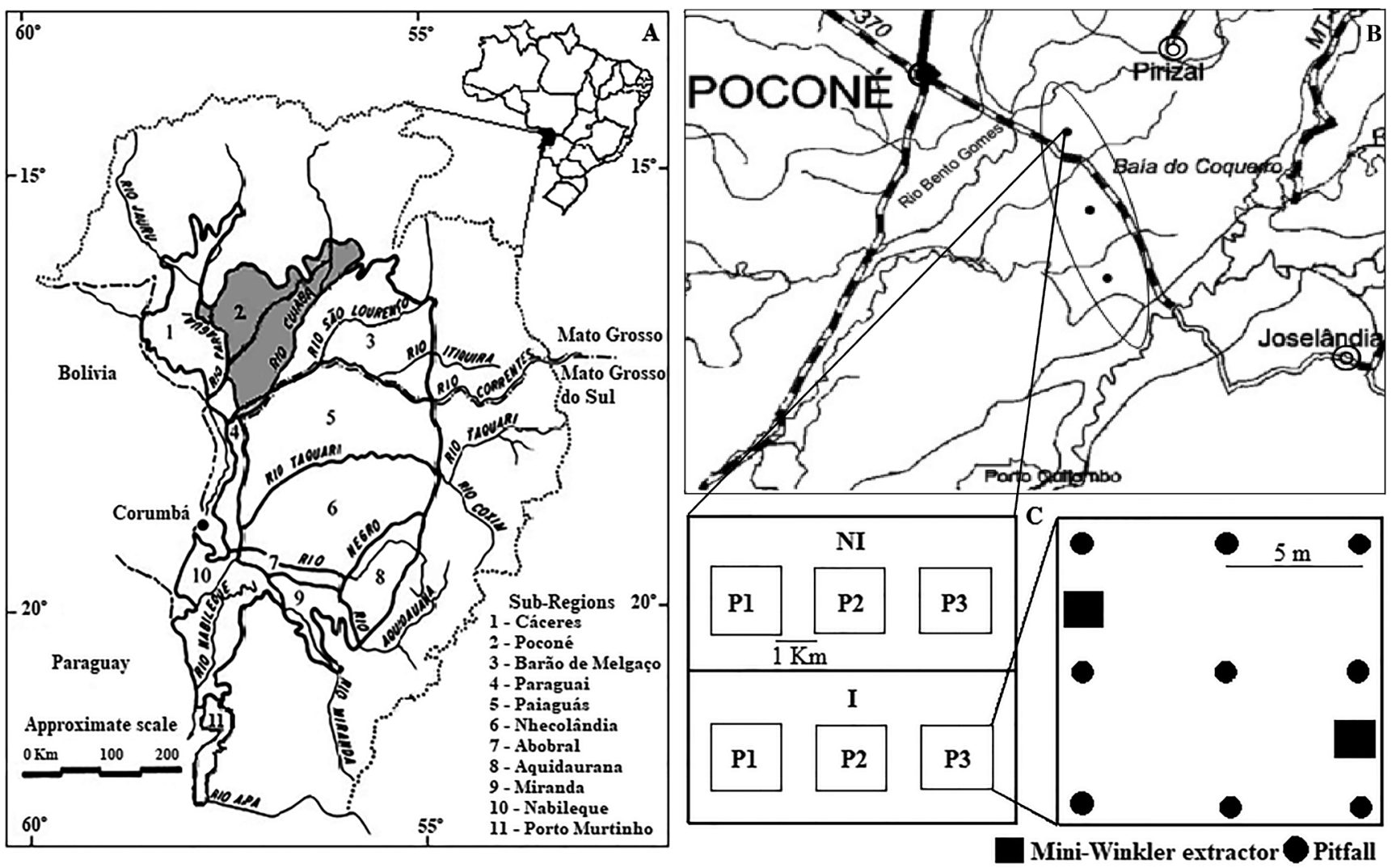

Figure 1. (A) The Pantanal and its 11 sub-regions, with emphasis on the Pantanal of Poconé, Mato Grosso, Brazil. (B) Study area with the location of the three sample units (A1, A2 and A3), along the Porto Cercado Road, between the Bento Gomes and Cuiabá rivers, within the floodplain of the Poconé Pantanal - MT. (C) Illustration indicating the inundated (I) and non- inundated (NI) habitats, with the three quadrats (P1, P2, P3) and layouts for the pitfall traps and mini-Winkler extractors. (Source: Silva et al. 2000, Meurer 2015, modified).

Due to the location of the inundation gradient, each area contains different vegetation formations. The Al area is predominantly mountainous in non-flooded areas, characterized by dense savanna tree vegetation (Silva et al. 2000, Nunes-da-Cunha et al. 2007, Fantin-Cruz et al. 2010), while sampling points located within floodplain habitats consist predominately of murundus fields (mounds of earth constructed by termites above the flood line). Woody cerrado vegetation is established within these fields due to the absence of flooding (Oliveira-Filho 1992, Nunes-da-Cunha et al. 2007, De Morais et al. 2013).

Area A2 is characterized by the presence of monodominant forest formations of Callisthene fasciculata (Spr.) Mart. (Vochysiaceae), with sparse grasses and herbaceous ground covers, and dense stands of Bromelia balansae Mez. and Ananas ananassoides (Baker) L.B. SM. (Bromeliaceae) (Nunes-da-Cunha et al. 2007). Sampling points within inundated areas correspond to fields dominated by Axonopus purpusii (Mez.). Chase and Reimarochloa brasilienses (Spreng.) (Poaceae), recognized for its high palatability and nutritional value to herds (Santos et al. 2012, Nunes-da-Cunha \& Junk 2015).

Area A3 contains stands of Attalea phalerata Mart. (Arecaceae) at the non-flooded sampling points (Santos et al. 2003, Nunes-da-Cunha et al. 2007), while the sampling points located within flooded areas correspond to mixed formations of evergreen flooded forests known as landizais and cerradões (Silva et al. 2000, Nunes-da-Cunha et al. 2007, Fantin-Cruz et al. 2010).

\section{Experimental Design}

Each sample area (A1, A2 and A3) was composed of two treatments; inundated (I) and non-inundated (NI) habitats. Within each habitat type, three quadrats $(10 \mathrm{~m} \times 10 \mathrm{~m})$ were delimited, considered sample points (P1, P2 and P3), where sampling was performed using pitfall traps (Adis 2002) and mini-Winkler extractors (Bestelmeyer et al. 2000).

At each sample point, nine pitfall traps were distributed five meters apart, totaling 27 pitfall traps per habitat type, 54 per area, and 162 traps per seasonal cycle consisting of the dry, rising water and receding water periods. During the high water period, only non-inundated habitats (NI) were sampled, as sampling in flooded areas (I) during inundation was considered unfeasible, thus 27 pitfall traps per area were used during the high water period, totaling 81 traps. The pitfall traps consisted of a polyethylene vial $20 \mathrm{~cm}$ in length, with a 5-6 cm diameter opening and contained $250 \mathrm{ml}$ of $4 \%$ formalin solution. Plastic protective covers $(20 \times 20 \mathrm{~cm})$ were used to shield the traps from rain and debris. All traps were buried at ground level to intercept moving arthropods and remained open in the field for seven days.

Mini-Winkler collectors were used to sample $2 \mathrm{~m}^{2}$ of leaf litter and superficial soil from each quadrat, totaling $6 \mathrm{~m}^{2}$ per habitat type, 12 $\mathrm{m}^{2}$ per area, and $36 \mathrm{~m}^{2}$ per seasonal cycle consisting of the dry, rising water and receding water periods. During the high water period, only non-inundated habitats (NI) were sampled, as sampling in flooded 
areas (I) during inundation was considered unfeasible, thus $6 \mathrm{~m}^{2}$ of leaf litter was sampled per area during the high water period, totaling 18 $\mathrm{m}^{2}$ during this period. Samples from the mini-Winkler collectors were taken to the laboratory, where they remained suspended for 72 hours in an air-conditioned environment for desiccation and, consequently, collection of arthropods from the collection flasks containing $70 \%$ alcohol.

The myriapods were separated from other arthropods in the laboratory, quantified and identified at the lowest possible taxonomic level by their respective specialists Amazonas Chagas Jr. (Chilopoda), Tamaris G. Pinheiro and Sergei Golovatch (Diplopoda). Specimens were placed into containers containing $70 \%$ alcohol. All sample material was deposited at the Biological Collection of Southern Amazonia (Acervo Biológico da Amazônia Meridional-ABAM), Federal University of Mato Grosso, Sinop-MT, Brazil. Sample data from the pitfall traps and mini-Winkler collectors was combined for analysis.

\section{Data Analysis}

The distribution of Myriapoda assemblages (Chilopoda and Diplopoda) was evaluated by entering the two annual hydrological cycles in the same data block. The Shapiro-Wilk test was used to evaluate the normality of the data. The variation in the composition of Myriapoda (Chilopoda and Diplopoda) assemblages between the seasonal periods (dry, rising water, high water and receding water) was evaluated through a Principal Coordinates Analysis (PCoA), based on the specie's abundance data matrix $(\log x+1)$, using the BrayCurtis similarity index. Subsequently, the two axes resulting from the ordination were analyzed using a Multivariate Analysis of Variance (MANOVA), adopting the Pillai Trace test.

To evaluate the temporal variation in Myriapoda species richness between the seasonal periods (dry, rising water, high water, receding water), sample areas (A1, A2 and A3), as well as between inundated (I) and non-inundated habitats, Generalized Linear Models (GLMs) with Poisson distribution for richness and Negative Binomial for abundance (based on Aikake and Bayesian evaluation criteria) were used. Species richness and its association to sampling was evaluated using the Jackknife 1 estimator. In all analyses, the adopted significance level was 0.05, using the R 3.4.1 program (R Development Core Team version 2017) Vegan package (Oksanen et al. 2017).

\section{Results}

\section{Assemblage Composition}

A total of 549 myriapods were collected; 407 Diplopoda and 142 Chilopoda, which were distributed among six orders, 12 families and 20 species (Table 1). Diplopoda is represented by three orders, seven families and 11 species, while three orders, five families and nine species make up the collected Chilopoda.

Diplopoda was predominated by Polydesmida (339 ind.; 83.1\%). Promestosoma boggianii (Silvestri, 1898) (295 ind.; 87\%) and Brasilodesmus sp. (37 ind.; 10.9\%) were most abundant. Cyrtodesmidae sp. (3 ind.; 0.9\%), Fuhrmannodesmidae sp. and Poratia salvator (1 ind.; $0.6 \%$ each) were poorly representated. The Spirostreptida Order was the second largest group among Diplopoda (67 ind.; 16.6\%), represented primarily by Trichogonostreptus (Oreastreptus) mattogrossensis
(Silvestri, 1902) (44 ind.; 65.7\%) and Plusioporus salvadorii (19 ind.; 28.4\%). Orthoporus (aff.) americanus (Silvestri, 1895) (2 ind.; 3\%), Urostreptus tampiitauensis (Schubart, 1947) and Urostreptus sp.1 (1 ind.; $1.5 \%$ each) revealed low abundance. Polyxenida also presented low abundance (Table 1).

Lithobiomorpha were the predominate Chilopoda, represented by Lamyctes sp. (93 ind.; 65.5\%), and followed by Scolopendromorpha (38 ind.; 26.8\%), principally Rhysida celeris (Humbert \& Saussure, 1870) (25 ind.; 65.8\%) and Otostigmus tidius Chamberlin, 1914 (Scolopendridae) (5 ind,; 13.2\%). Geophilomorpha were the least abundant chilopods, with only 11 specimens of Schendylops inquilinus Pereira et al. 2007 (Schendylidae) (7.7\%) (Table 1).

The 20 species obtained corresponded to $80 \%$ of the Jackknife 1 estimator expected richness (25.9 spp.), showing sampling efficiency. The composition of myriapod assemblages varied throughout the seasonal periods. The two Principal Components Analysis (PCoA) axes captured $78 \%$ of the variation in assemblage composition. The ordination of myriapod species abundance between seasonal periods showed temporal variation in assemblage structure (MANOVA, $\mathrm{F}=4.875 ; \mathrm{df}=3 ; \mathrm{P}<0.001)$. This ordination indicated that the rising water and dry periods differed from the high water and receding water periods in relation to the composition of Myriapoda assemblages (Figure 2). The greatest variations in relation to abundance were found during the dry and rising water periods ( $87.8 \%$ of sampled individuals), compared to the high water and receding water periods $(12.2 \%$ of assemblage abundance).

\section{Assemblage Richness and Abundance}

The species richness of Myriapoda assemblages varied between the seasonal periods (GLM, $\mathrm{Z}=-2.72, \mathrm{P}<0.001$ ) (Figure $3 \mathrm{~A}$ ). No variation was observed in relation to the abundance of myriapods (GLM, $\mathrm{Z}=-1.68, \mathrm{P}=0.09$ ) (Figure $3 \mathrm{~B}$ ). The rising water (13 spp; 30.2\%), dry (12 spp.; 27\%) and high water (11 spp.; 25.6\%) seasonal periods corresponded to the highest species richness, while the receding water period revealed just seven species $(16.3 \%)$. In relation to abundance, the rising water (269 ind.; $49 \%$ ) and dry (213 ind.; 38.8\%) periods had the highest number of individuals, while the receding water (48 ind.; 8.7\%) and dry (19 ind.; 3.5\%) periods registered the least records (Figure $3 \mathrm{~B}$ ).

Considering the seasonal periods, it was observed that $R$. celeris, $S$. inquilinus, Lamyctes sp. and T. (O.) mattogrossensis occurred throughout the year. However, Newportia (Tidops) balzanii Silvestri, 1895 (Scolopocryptopidae), Scolopendra viridicornis Newport, 1844 (Scolopendridae) and Fuhrmannodesmidae sp. were sampled only during the high water period. Other taxa such as Newportia (Tidops) sp., P. salvator and Polyxenida were sampled only during the rising water period, while Urostreptus sp. and U. tampiitauensis, were sampled exclusively in the dry period. During the receding water period there was no record of exclusive occurrence for any of the myriapod species.

Myriapod richness was different between areas A1, A2 and A3 (GLM, $\mathrm{Z}=1.89, \mathrm{P}=0.05$ ) (Figure $3 \mathrm{~A}$ ), similar to that observed in relation to species abundance (GLM, $Z=4.30, P<0.001$ ) (Figura 3 B). For the A1 area a large number of exclusive species were found, including $S$. viridicornis, Urostreptus sp., U. tampiitauensis, O. (aff.) americanus and Polyxenida. Brasilodesmus sp., Cyrtodesmidae sp., Fuhrmannodesmidae sp., and Newportia (Tidops) sp. were sampled only in area A3. Area A2 showed a greater abundance of individuals 
Table 1. Abundance distribution of Diplopoda and Chilopoda between seasonal periods $(\mathrm{DS}=$ Dry season, $\mathrm{RW}=\mathrm{Rising}$ water, $\mathrm{HW}=\mathrm{High}$ water, $\mathrm{RE}=\mathrm{Receding}$ water), inundated (I) and non-inundated (NI) habitats, as well as between the different phytophysiognomies $(\mathrm{AC}=$ Attalea phalerata stands, $\mathrm{CL}=\mathrm{Field}$, $\mathrm{CM}=$ Murundu Field, $\mathrm{CR}=$ Callisthene fasciculata Forest, $\mathrm{CE}=$ Cerradão, $\mathrm{LM}=$ Landizal); and indication of the collection methodology (EMW = Mini-Winkler collector and PTR = pitfall traps) used in a floodplain of the northern Pantanal region of Mato Grosso, Brazil.

\begin{tabular}{|c|c|c|c|c|c|c|c|c|c|c|c|c|c|c|}
\hline \multirow[t]{2}{*}{ Táxon } & \multirow[b]{2}{*}{ DS } & \multicolumn{3}{|c|}{ Seasonal Periods } & \multicolumn{2}{|c|}{ Habitats } & \multicolumn{7}{|c|}{ Phytophysiognomies } & \multirow[t]{2}{*}{$\begin{array}{c}\text { Collection } \\
\text { Methodology }\end{array}$} \\
\hline & & RW & HW & $\mathbf{R E}$ & $\mathbf{I}$ & NI & $\mathrm{CO}$ & $\mathbf{C M}$ & CR & $\mathbf{C L}$ & $\mathbf{A C}$ & CE & $\mathbf{L M}$ & \\
\hline \multicolumn{15}{|l|}{ Diplopoda } \\
\hline \multicolumn{15}{|l|}{ Polydesmida } \\
\hline \multicolumn{15}{|l|}{ Chelodesmidae } \\
\hline Brasilodesmus sp. ${ }^{(1)}$ & 36 & 1 & - & - & 18 & 19 & - & - & - & - & 19 & 18 & - & EMW, PTR \\
\hline Cyrtodesmidae sp. ${ }^{(2)}$ & 2 & 1 & - & - & 1 & 2 & - & - & - & - & 2 & - & 1 & PTR \\
\hline \multicolumn{15}{|l|}{ Fuhrmannodesmidae } \\
\hline Fuhrmannodesmidae sp. ${ }^{(3)}$ & - & - & 2 & - & - & 2 & - & - & - & - & 2 & - & - & EMW \\
\hline \multicolumn{15}{|l|}{ Paradoxosomatidae } \\
\hline Promestosoma boggianii (Silvestri, 1898) ${ }^{(4)}$ & 76 & 209 & - & 10 & 182 & 113 & 1 & 3 & 79 & 147 & 33 & 23 & 9 & EMW, PTR \\
\hline \multicolumn{15}{|l|}{ Pyrgodesmidae } \\
\hline Polyxenidae $^{(6)}$ & - & 1 & - & - & 1 & - & - & 1 & - & - & - & - & - & PTR \\
\hline \multicolumn{15}{|l|}{ Spirostreptida } \\
\hline \multicolumn{15}{|l|}{ Spirostreptidae } \\
\hline Orthoporus (aff.) americanus (Silvestri, 1895) & 1 & - & 1 & - & - & 2 & 2 & - & - & - & - & - & - & PTR \\
\hline Plusioporus salvadorii Silvestri, $1895^{(8)}$ & 7 & 12 & - & - & 1 & 18 & - & - & 17 & 1 & 1 & - & - & EMW, PTR \\
\hline $\begin{array}{l}\text { Trichogonostreptus (Oreastreptus) } \\
\text { mattogrossensis (Silvestri, 1902) }\end{array}$ & 28 & 6 & 4 & 6 & 18 & 26 & 4 & 7 & 18 & 8 & 4 & 2 & 1 & EMW, PTR \\
\hline Urostreptus $\mathrm{sp}^{\left({ }^{(10)}\right.}$ & 1 & - & - & - & - & 1 & 1 & - & - & - & - & - & - & PTR \\
\hline Urostreptus tampiitauensis (Schubart, 1947) ${ }^{(11)}$ & 1 & - & - & - & 1 & - & 1 & - & - & - & - & - & - & PTR \\
\hline \multicolumn{15}{|l|}{ Chilopoda } \\
\hline Scolopendridae & & & & & & & & & & & & & & \\
\hline Otostigmus sp. ${ }^{(15)}$ & - & - & 1 & 1 & 1 & 1 & 1 & - & - & - & - & 1 & - & PTR \\
\hline Otostigmus tidius Chamberlin, $1914^{(16)}$ & 2 & 2 & - & 1 & 1 & 4 & 2 & 1 & 1 & - & 1 & - & - & PTR \\
\hline Rhysida celeris (Humbert \& Saussure, 1870) $)^{(17)}$ & 19 & 2 & 2 & 2 & 5 & 20 & 14 & 4 & 6 & - & - & 1 & - & EMW, PTR \\
\hline Scolopendra viridicornis Newport, 1844(18) & - & - & 1 & - & - & 1 & 1 & - & - & - & - & - & - & PTR \\
\hline Geophilomorpha $^{(5)}$ & & & & & & & & & & & & & & \\
\hline Schendylidae & & & & & & & & & & & & & & \\
\hline Schendylops inquilinus Pereira et al., $2007^{(19)}$ & 3 & 3 & 2 & 3 & 2 & 9 & 5 & 1 & 2 & 1 & 1 & - & 1 & EMW \\
\hline Lithobiomorpha $^{(6)}$ & & & & & & & & & & & & & & \\
\hline Henicopidae & & & & & & & & & & & & & & \\
\hline Lamyctes sp. ${ }^{(20)}$ & 37 & 28 & 3 & 25 & 57 & 36 & 2 & 20 & 16 & 30 & 18 & 4 & 3 & EMW, PTR \\
\hline Total & 213 & 269 & 19 & 48 & 289 & 260 & 36 & 37 & 139 & 188 & 84 & 49 & 16 & \\
\hline & & & & & & & & & & 549 & & & & \\
\hline
\end{tabular}

Registration number in ABAM: (1) - Abam/Diplopoda/0287; (2) - Abam/Diplopoda/0288; (3) - Abam/Diplopoda/0289; (4) - Abam/Diplopoda/0290; (5) - Abam/ Diplopoda/0291; (6) - Abam/Diplopoda/0292; (7) - Abam/Diplopoda/0293; (8) - Abam/Diplopoda/0294; (9) - Abam/Diplopoda/0295; (10) - Abam/Diplopoda/0296; (11) - Abam/Diplopoda/0297; (12) - Abam/Chilopoda/0002; (13) - Abam/Chilopoda/0003; (14) - Abam/Chilopoda/0004; (15) - Abam/Chilopoda/0005; (16) - Abam/ Chilopoda/0006; (17) - Abam/Chilopoda/0007; (18) - Abam/Chilopoda/0008; (19) - Abam/Chilopoda/0009; (20) - Abam/Chilopoda/0010. 


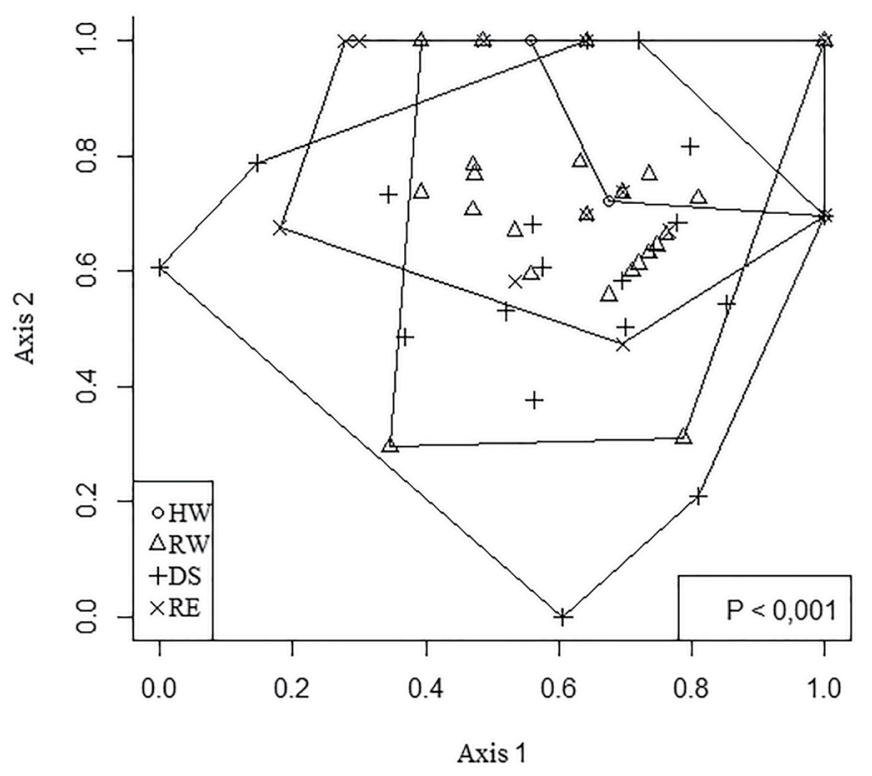

Figure 2. Principal Component Analysis ( $\mathrm{PCoA}$ ) of myriapod composition (Chilopoda and Diplopoda), arranged in two axes, considering the four seasonal periods $(\mathrm{DS}=$ Dry season, $\mathrm{RW}=$ Rising water, $\mathrm{HW}=$ High water and $\mathrm{RE}=$ Receding water) of the northern Pantanal region of Mato Grosso, Brazil.
(327 ind.; 59.6\%), followed by area A3 (149 ind.; 27.1\%) and area A1 (73 ind.; 13.3\%). Otostigmus tidius, $R$. celeris, S. inquilinus, Lamyctes sp. and $P$. boggianii were found in all sampled areas.

The inundated and non-inundated habitats did not vary between species, both in regards to species richness $(\mathrm{GLM}, \mathrm{Z}=-0.19, \mathrm{P}=0.8$ ) and myriapod abundance $(\mathrm{GLM}, \mathrm{Z}=-0.98, \mathrm{P}=0.3)$. Although not varied, the number of individuals in inundated habitats (289 ind.; $52.6 \%$ ) was higher than that observed in non-inundated habitats (260 ind.; $47.4 \%$ ) (Table 1). Comparing the species found between inundated and non-inundated habitats, it was observed that nine species were common to both environments, nine were sampled only in non-inundated habitats, and two only in inundated environments (Table 1).

In regards to the different vegetation formations present in the sample areas, it was observed that the fields (188 ind.; $34.2 \%$ ) and $C$. fasciculata forests (139 ind.; $25.3 \%$ ) were more abundant, followed by areas of $A$. phalerata stands ( 84 ind.; 15.3\%), cerradão (49 ind.; 8.9\%), murund $u$ fields (37 ind.; 6.7\%), mountain ranges (36 ind.; 6.6\%) and landizal (16 ind.; 2.9\%). Evaluating the distribution of the constituent species of these assemblages, only P. boggianii, Lamyctes sp. and $T$. (O.) mattogrossensis were recorded in all vegetation types. Scolopendra viridicornis, Urostreptus sp., and U. tampiitauensis, O. (aff.) americanus occurred exclusively in mountainous areas. Fuhrmannodesmidae sp.
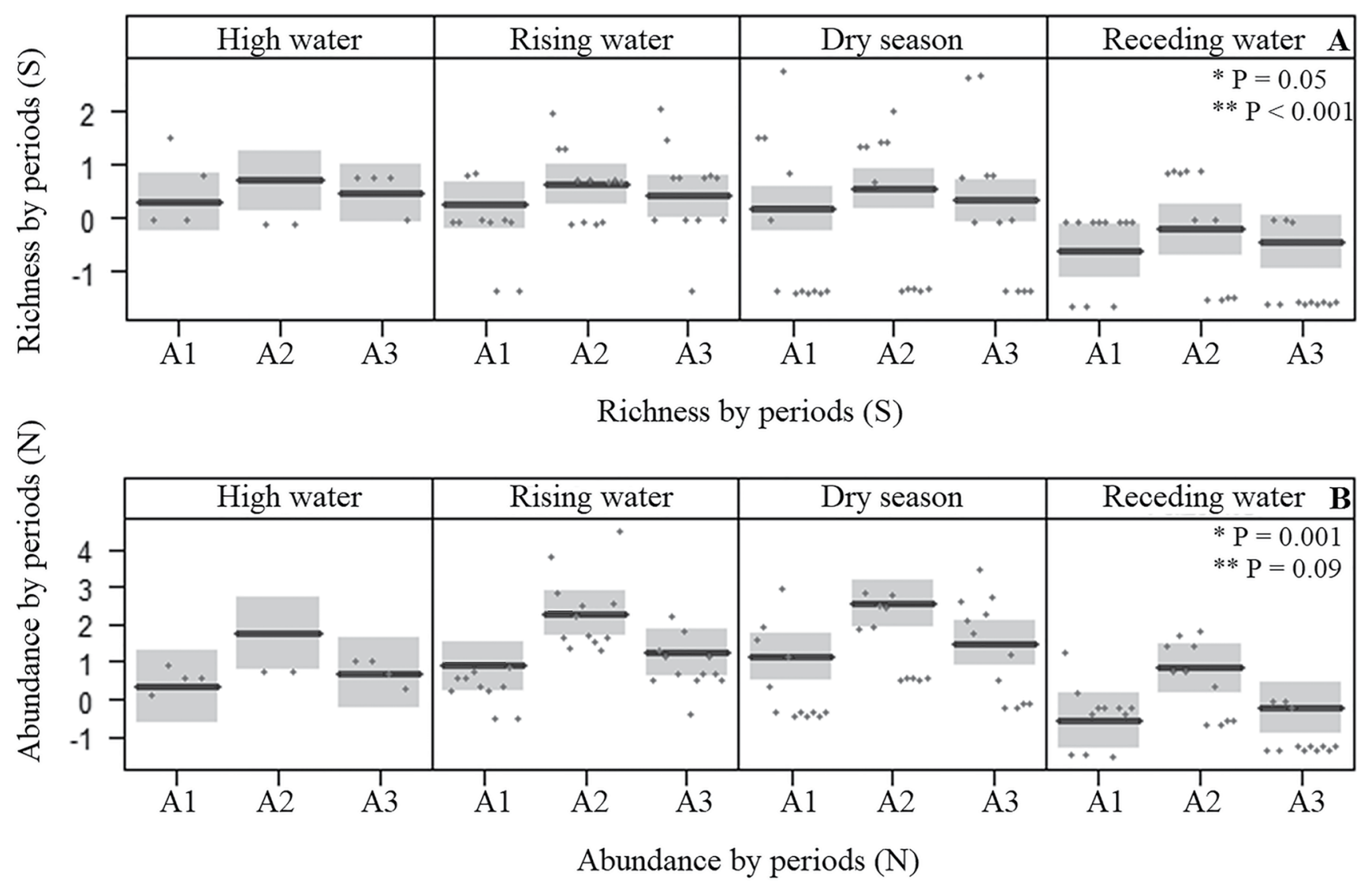

Figure 3. Myriapod distribution (Diplopoda and Chilopoda) in relation to seasonal periods, sample areas and richness (A), seasonal periods, sample areas and abundance (B), in a floodplain of the northern Pantanal region of Mato Grosso, Brazil. * Value of P for area, ** value of P for seasonal period. 
and Newportia (Tidops) sp. were recorded only in areas of $A$. phalerata (Table 1).

\section{Discussion}

Myriapod assemblages and their structure are still poorly explored in Neotropical region, particularly in wetlands such as the Pantanal (e. g. Adis et al. 2001, Golovatch et al. 2005, Pereira et al. 2007, Pinheiro et al. 2009, 2011, Battirola et al. 2009, Wantzen et al. 2016). In the present study, 20 species of Chilopoda and Diplopoda were sampled, a value higher than that obtained in other surveys conducted in the same region of the Pantanal (Golovatch et al. 2005, Battirola et al. 2017c, Battirola et al. 2009), and similar to those found in the Amazon of Mato Grosso (Battirola et al. 2011, 2016a). The knowledge gap in regards to these invertebrates is confirmed by the new records of two families of Polydesmida (Diplopoda), Cyrtodesmidae and Fuhrmannodesmidae sampled for the first time in the Mato Grosso Pantanal, expanding the list of known Myriapoda taxa for this region. Cyrtodesmidae and Fuhrmannodesmidae species correspond to small and common diplopods in the wetlands of central Amazonia (Golovatch 2001, Adis et al. 2002, Hoffman et al. 2002).

The results obtained allow the inference that the composition, richness and abundance of myriapod assemblages vary according to the region's hydrological seasonality, as well as the structural conditions provided by the different habitats present in this floodplain in the northern Pantanal region of Mato Grosso. The dry and rising water phases corresponded to the seasonal periods of greater abundance and movement of myriapods between inundated and non-inundated habitats, as well as the periods with the highest recorded species richness. This pattern of movement, with a considerable increase in the abundance and richness of myriapod fauna in the dry and rising water periods is a result of the influence of environmental changes which occur between the end of the dry season and the beginning of the rainy (rising water) season, providing greater moisture availability and, consequently, better survival conditions and resources for myriapods in these environments (e. g. Adis et al. 2001, Pinheiro et al. 2009, 2011, Marques et al. 2011, Battirola et al. 2009). This variation substantiates the specificity of flooded ecosystems and their dependence on seasonal hydrological changes (e.g. Junk 1993).

An additional relevant factor that contributes to this pattern of movement and occurrence is the hydrological stress caused by seasonal flooding during the rising water and high water periods, when most of the terrestrial habitats present in the floodplain are affected at different flood levels, altering the structural conditions of these environments and hindering the survival of invertebrate fauna in the edaphic environment (Castilho et al. 2005; Signor et al. 2010; Marques et al. 2014; Junk et al. 2015; Battirola et al. 2017a,b). This variation substantiates the specificity of flooded ecosystems and their dependence on seasonal hydrological changes (e.g. Junk 1993).

The effect of periodic changes to habitat structure caused by the hydrological regime can be verified in the present study by the distribution of $P$. boggianii abundance throughout the different seasonal periods, enabling the assumption that this species migrates between inundated and non-inundated habitats to favorable environmental conditions. The Promestosoma boggianii population is seasonally distributed, occupying primarily inundated and non-inundated habitats during dry and rising water periods, and decreasing severely in numbers in these areas during the receding water and high water periods. This pattern of habitat occupation between seasonal periods can be interpreted as a survival strategy developed by this species in response to the sudden changes in environmental conditions which alter the distribution of resources, such as the variety and quantity of leaf litter, breeding habitat, shelter against flooding or desiccation during dry periods, aspects considered to be influencing factors on these invertebrates (Adis et al. 2001, Battirola et al. 2009, Pinheiro et al. 2009, 2011, Marques et al. 2011).

These temporary displacements between habitats and the synchronism in life cycle development of some species according to the hydrological conditions of the northern Pantanal region were recorded for the diplopods $P$. salvator and $P$. boggianii, which adapted their life cycle, reproduction and phenology to the region's flood cycles (Pinheiro et al. 2009, 2011, Wantzen et al. 2016, Santos-Silva et al. 2018), as well as for the chilopods $R$. celeris and S. inquilinus (Battirola et al. 2017c), and other groups of terrestrial arthropods (Adis et al. 2001, Castilho et al. 2005, Marques et al. 2014, Yamazaki et al. 2015).

In other wetlands such as Central Amazonia, several known survival strategies are employed by myriapods such as the vertical migration from soil to tree trunks and canopy at the beginning of the flooding period, which have been recorded for Epinannolene exilio (Brölemann, 1904) (Pseudonannolenidae) and Poratia insularis (Kraus, 1960) (Pyrgodesmidae) (Golovatch et al. 1997, Bergholz et al. 2004), and Myrmecodesmus adisi (Hoffman 1985) (Pyrgodesmidae), a semi-aquatic species that has a morphological adaptation which renders it resistant to flooding, enabling it to survive submerged in the forest substrate for long periods (Adis 1986, Golovatch 1999, Adis et al. 2003). Lamyctes adisi Zalesskaja, 1994 (Henicopidae) developed eggs resistant to submersion, which allows it to synchronize its reproduction with dry and inundated periods, ovipositing in the soil before flooding, so that hatching occurs soon after the receding water period (Adis 1992, Foddai et al. 2002).

In addition to the influence of the region's seasonality on the temporal distribution of Chilopoda and Diplopoda assemblages, the conditions of the different habitats present in the inundation gradient and their vegetative characteristics can be considered important factors in the occupation of these areas by myriapods. It was observed that the different species of myriapods that inhabit this flood plain occupy the most varied habitats available, however, significant variations are evidenced in their abundance patterns between habitats, allowing the assumption that the structure of the environment has a greater influence on the population's abundance than the number of myriapod species in this gradient.

Despite the high similarity between inundated and non-inundated environments, myriapods were more abundant in inundated habitats. Areas A2 and A3, susceptible to a greater flood amplitude, also had a higher number of myriapods in comparison to area A1, indicating that habitats which are wetter for longer periods throughout the year provide better conditions of permanence and reproduction for these individuals. These results demonstrate that non-inundated areas, due to their structure and different vegetation types, can function as refuge, shelter, breeding and feeding sites for certain species of Chilopoda and Diplopoda during periods when the lower parts of the plains in the Pantanal are subject to inundation, as was observed for other arthropods adapted to these seasonal conditions (Battirola et al. 2010, 2016b, 2017a,b, Aranda 2013, Marques et al. 2011, 2014, Meurer et al. 2015, Yamazaki et al. 2015). 
In general, these results conclude that the composition, richness and abundance of myriapod assemblages associated with this floodplain are susceptible to the temporal and spatial variations of this ecosystem, due to the seasonal hydrological conditions and their specific effects on the structure of the environment in both inundated and non-inundated habitats characteristic of this important wetland. In addition, seasonally flooded areas such as the Pantanal of Mato Grosso play an important role in the maintenance of biological diversity, due to the vegetation mosaic which offers various habitats and niches that, combined with the hydrological dynamics, provide a wide variety of fauna resources (e.g. Alho 2008). Consequently, conservation of the Pantanal is directly linked to the preservation of its vegetation structure (Alho \& Sabino 2011), which is used by vertebrates and invertebrates such as Chilopoda and Diplopoda for the habitat and resources it provides. Thus, management and environmental protection plans for the Pantanal of Mato Grosso should consider the magnitude of the regional macrohabitats, protecting the structural and functional integrity of the wetlands, as well as their biodiversity.

\section{Acknowledgement}

We thank the Pantanal Research Center (Centro de Pesquisas do Pantanal-CPP), the National Institute of Science and Technology in Wetlands (Instituto Nacional de Ciência e Tecnologia em Áreas Úmidas - INAU/UFMT/CNPq), the Mato Grosso Foundation for Research Support (Fundação de Amparo à Pesquisa do Estado de Mato Grosso -FAPEMAT) (Process PRONEX/FAPEMAT/CNPq 838265/2009) and the National Council for Scientific and Technological Development (Conselho Nacional de Desenvolvimento Científico e Tecnológico - CNPq) (Process 472215/2013-2) for their financial assistance and provision of logistics to the study. The Coordination of Improvement of Higher Education Personnel (Coordenação de Aperfeiçoamento de Pessoal de Nivel Superior-CAPES) for the granting of a scholarship to LSS. The Federal University of Mato Grosso, specifically, the Graduate Program in Environmental Sciences (Universidade Federal de Mato Grosso - UFMT, Sinop).

\section{Authors' Contributions}

Leandro Dênis Battirola and Marinêz Isaac Marques: substantial contribution in the concept and design of the study;

Leandro Dênis Battirola, Marinêz Isaac Marques and Lorhaine Santos-Silva: contribution to data collection;

Tamaris Gimenez Pinheiro and Amazonas Chagas-Jr: contribution to identified Diplopoda and Chilopoda;

Lorhaine Santos-Silva and Leandro Dênis Battirola: contribution to data analysis and interpretation;

Lorhaine Santos-Silva and Leandro Dênis Battirola: contribution to manuscript preparation;

Tamaris Gimenez Pinheiro, Amazonas Chagas-Jr and Marinêz Isaac Marques: contribution to critical revision, adding intellectual content.

\section{Conflicts of interest}

The authors declares that they have no conflict of interest related to the publication of this manuscript.

\section{References}

ADIS, J. 1986. An "aquatic" millipede from a Central Amazonian inundation forest. Oecologia 68:347-349. https://doi.org/10.1007/BF01036737

ADIS, J. 1992. How to survive six months in a flooded soil: Strategies in Chilopoda and Symphyla from Central Amazonian floodplains. Stud. Neotrop. Fauna E. 27:(2-3)117-129. http://dx.doi.org/10.1080/01650529209360872

ADIS, J. 1997. Estratégias de sobrevivência de invertebrados terrestres em florestas inundáveis da Amazônia Central: Uma resposta à inundação de longo período. Acta Amaz. 27:43-54. 1809-4392-aa-27-1-0043

ADIS, J. 2002. Recommended sampling techniques. In Amazonian Arachnida and Myriapoda (J. Adis ed.). Pensoft Publishers, Sofia, p. 555-576.

ADIS, J. \& HARVEY, M.S. 2000. How many Arachnida and Myriapoda are there world-wide and in Amazonia. Stud. Neotrop. Fauna E. 35:139-141. http://hdl.handle.net/11858/00-001M-0000-000F-E060-1

ADIS, J., MARQUES, M.I. \& WANTZEN, K.M. 2001. First observations on the survival strategies of terriculous arthropods in the northern Pantanal wetland of Brazil. Andrias 15:127-128.

ADIS, J., FODDAI, D., GOLOVATCH, S.I., HOFFMAN, R.L., MINELLI, A., DE MORAIS, J.W., PEREIRA, L.A., SCHELLER, U., SCHILEYKO, A.A. \& MÜRMLI, M. 2002. Myriapoda at 'Reserva Ducke', Central Amazonia/ Brazil. Amazoniana 17(1-2):14-25.

ADIS, J., GOLOVATCH, S.I. \& MESSNER, B. 2003. Morphological structures in some Neotropical Myrmecodesmus species (Diplopoda: Polydesmida: Pyrgodesmidae) reveal the ability for plastron respiration. Arthropoda Sel. 12(1):17-21.

ALHO, C.J.R. 2008. Biodiversity of the Pantanal: Response to seasonal flooding regime and to environmental degradation. Braz. J. Biol. 68(4):957-966. 10.1590/S1519-69842008000500005

ALHO, C.J.R. \& SABINO, J. 2011. A conservation agenda for the Pantanal's biodiversity. Braz. J. Biol. 71(1):327-335. 10.1590/S151969842011000200012

ARANDA, R. 2013. Capões como ilhas para artrópodes no Pantanal. EntomoBrasilis 6(3):173-177. 10.12741/ebrasilis.v6i3.331.

ARIEIRA, J. \& NUNES-DA-CUNHA, C. 2006. Fitossociologia de uma floresta inundável monodominante de Vochysia divergens Pohl. (Vochysiaceae), no Pantanal Norte, MT, Brasil. Acta Bot. Bras. 20(3):569-580. 10.1590/ S0102-33062006000300007

BATTIROLA, L.D., MARQUES, M.I., ROSADO-NETO, G.H., PINHEIRO, T.G. \& PINHO, N.G.C. 2009. Vertical and time distribution of Diplopoda (Arthropoda, Myriapoda) in a monodominant forest in Pantanal of Mato Grosso, Brazil. Zoologia 26:479-487. 10.1590/S1984-46702009005000008

BATTIROLA, L.D., MARQUES, M.I., BRESCOVIT, A.D., ROSADO NETO, G.H. \& ANJOS, K.C. 2010. Comunidade edáfica de Araneae (Arthropoda, Arachnida) em uma floresta sazonalmente inundável na região norte do Pantanal de Mato Grosso, Brasil. Biota Neotropica 10(2) http:/www. biotaneotropica.org.br/v1 0n2/pt/abstract?inventory+bn00210022010

BATTIROLA, L.D., BRESCOVIT, A.D., PENA-BARBOSA, J.P.P., PINHEIRO, T.G. \& BATISTELLA, D.A. 2011. Diplopoda (Myriapoda, Arthropoda) da Fazenda São Nicolau, Cotriguaçu-MT. In Descobrindo a Biodiversidade da Fazenda São Nicolau (D.J. Rodrigues, T.J. Izzo \& L.D. Battirola, eds.). Pau e Prosa Comunicação Ltda, Cuiabá, p. 35-46.

BATTIROLA, L.D., SANTOS-SILVA, L., ALMEIDA, F.M., BATISTELLA, D.A., PENA-BARBOSA, J.P.P., CHAGAS-JUNIOR, A. \& BRESCOVIT, A.D. 2016a. Artrópodes de solo do Parque Estadual do Cristalino, Mato Grosso. In Biodiversidade do Parque Estadual Cristalino (D.D.J. Rodrigues, J.D.C.D. Noronha, V.F. Vindica \& F.R. Barbosa, eds.). Áttema Editorial, Santo André-SP, p. 165-177.

BATtirola, L.D., BATISTELlA, D.A., ROSADO-NETO, G.H., BRESCOVIT, A.D. \& MARQUES, M.I. 2016b. Spider assemblage (Arachnida: Araneae) associated with canopies of Vochysia divergens (Vochysiaceae) in the northern region of the Brazilian Pantanal. Zoologia 33(4):1-9. 10.1590/S1984-4689zool-20150170 
BATTIROLA, L.D., ROSADO-NETO, G.H., BATISTELLA, D.A., MAHNERT, V., BRESCOVIT, A.D. \& MARQUES, M.I., 2017a. Vertical and time distribution of Pseudoscorpiones (Arthropoda: Arachnida) in a floodplain forest in the Brazilian Pantanal. Rev. Biol. Trop. 65(2): 445-459. https:// doi.org/10.15517/rbt.v65i2.24134

BATTIROLA, L.D., SANTOS, G.B., MEURER, E., CASTILHO, A.C.C., MAHNERT, V., BRESCOVIT, A.D. \& MARQUES, M.I. 2017b. Soil and canopy Pseudoscorpiones (Arthropoda, Arachnida) in a monodominant forest of Attalea phalerata Mart. (Arecaceae) in the Brazilian Pantanal. Stud. Neotrop. Fauna E. 52 (2):1-8. http://dx.doi.org/10.1080/01650521. 2017.1282210

BATTIROLA, L.D., GOLOVATCH, S.I., PINHEIRO, T.G., BATISTELLA, D.A., ROSADO-NETO, G.H., CHAGAS JR, A., BRESCOVIT, A.D. \& MARQUES, M.I. 2017c. Myriapod (Arthropoda, Myriapoda) diversity and distribution in a floodplain forest of the Brazilian Pantanal. Stud. Neotrop. Fauna E. http://dx.doi.org/10.1080/01650521.2017.1397978

BERGHOLZ, N.G.R., ADIS, J. \& GOLOVATCH, S.I. 2004. The millipede Poratia insulares (Kraus, 1960) new to the fauna of Brazil (Diplopoda: Polydesmida: Pyrgodesmidae). Arthropoda Sel. 13(3):123-127.

BESTELMEYER, B.T., AGOSTI, D., LEEANNE, F., ALONSO, T., BRANDÃO, C.R.F., BROWN, W.L., DELABIE, J.H.C. \& SILVESTRE, R. 2000. Field techniques for the study of ground-living ants: An Overview, description, and evaluation. In Ants: standart methods for measuring and monitoring biodiversity (D. Agosti, J.D. Majer, A. Tennant \& T. de Schultz, eds.). Smithsonian Institution Press, Washington, p. 122-144.

BREWER, M.S., SIERWALD, P. \& BOND, J.E. 2012. Millipede taxonomy after 250 years: Classification and taxonomic practices in a mega-diverse yet understudied arthropod group. Plos One 7(5):e3724. 10.1371/journal. pone. 0037240

CASTILHO, A.C.C., MARQUES, M.I., ADIS, J. \& BRESCOVIT, A.D. 2005. Distribuição sazonal e vertical de Araneae em área com predomínio de Attalea phalerata Mart. (Arecaceae), no Pantanal de Poconé, Mato Grosso, Brasil. Amazoniana 18: 215-239. http://hdl.handle.net/11858/00-001M0000-000F-D965-3

DE MORAIS, R.F., DA SILVA, E.C.S., METELO, M.R.L. \& DE MORAIS, F.F. 2013. Composição florística e estrutura da comunidade vegetal em diferentes fitofisionomias do Pantanal de Poconé, Mato Grosso. Rodriguésia 64(4):775-790. http://dx.doi.org/10.1590/S2175-78602013000400008.

EDGECOMBE, G.D. \& GIRIBET, G. 2007. Evolutionary biology of centipedes (Myriapoda: Chilopoda). Annu. Rev. Entomol. 52:151-70. 10.1146/annurev. ento.52. 110405.091326

ENGHOFF, H., GOLOVATCH, S., SHORT, M., STOEV, P. \& WESENER, T. 2015. Diplopoda, taxonomic overwiew. In The Myriapoda 2 (A. Minelli ed.). Koninklijke Brill NV, Leiden, p. 363-453.

FANTIN-CRUZ, I., GIRARD, P., ZEILHOFER, P., COLLISCHONN, W. \& NUNES-DA-CUNHA, C. 2010. Unidades fitofisionômicas em mesoescala no Pantanal Norte e suas relações com a geomorfologia. Biota Neotropica 10(2) http://www.biotaneotropica.org.br/v10n2/pt/ abstract?article+bn00410022010

FERREIRA, C.D.P. \& CASATTI, L. 2006. Influência da estrutura do habitat sobre a ictiofauna de um riacho em uma micro-bacia de pastagem, São Paulo, Brasil. Rev. Bras. Zool. 23(3):642-651. 10.1590/S010181752006000300006 .

FODDAI, D., SCHILEYKO, A.A. \& MINELLI, A. 2002. Lithobiomorpha. In Amazonian Arachnida and Myriapoda (J. Adis, ed.). Pensoft Publishers, Sofia, p. 475-478.

FREITAS, A.V.L., LEAL, I.R., UEHARA-PRADO, M. \& IANNUZZI, L. 2006. Insetos como indicadores de conservação da paisagem. In Biologia da Conservação (C.F. Rocha, H. Bergalo, M.V. Sluys \& M.A. Alves, eds.). Essências, Rima Editora, São Carlos, p. 357-384.

GIACOMINI, H.C. 2007. Os mecanismos de coexistência de espécies como vistos pela teoria ecológica. Oecol. Bras. 11(4):521-543. 10.4257/ oeco.2007.1104.05.

GOLOVATCH, S.I. 1999. On six new and some older Pyrgodesmidae from the environs of Manaus, Central Amazonia, Brazil (Diplopoda, Polydesmida). Amazoniana 15: 221-238.
GOLOVATCH, S.I. 2001. Two new polydesmoid millipedes from a white sand forest área near Manaus, Central Amazonia, Brazil (Diplopoda, Polydesmida: Pyrgodesmidae, Fuhrmannodesmidae). Arthropoda Sel. 10(1): 27-30.

GOLOVATCH, S.I., HOFFMAN, R.L., ADIS, J. \& DE MORAIS, J.W. 1995. Identification plate for the millipede orders populating the Neotropical region south of Central Mexico (Myriapoda, Diplopoda). Stud. Neotrop. Fauna E. 30:159-164. 10.1080/01650529509360954

GOLOVATCH, S.I., HOFFMAN, R.L., ADIS, J., VOHLAND, K. \& MÁRMOL, A. 1997. On the identity of further two millipede species (Diplopoda) from the environs of Manaus, Central Amazonia, Brazil. Amazoniana 14: 301-309.

GOLOVATCH, S.I., HOFFMAN, R.L., ADIS, J., MARQUES, M.I., RAIZER, J., SILVA, F.H.O., RIBEIRO, R.A.K., SILVA, J.L. \& PINHEIRO, T.G. 2005. Milipedes (Diplopoda) of the Brazilian Pantanal. Amazoniana 18(34):273-288. 11858/00-001M-0000-000F-D961-B

GUIZZE, S.P.G., KNYSAK, I., BARBARO, K.C., KARAM-GEMAEL, M. \& CHAGAS-JR, A. 2016. Predatory behavior of three centipede species of the order Scolopendromorpha (Arthropoda: Myriapoda: Chilopoda). Zoologia 33(6): e20160026.10.1590/S1984-4689zool-20160026

HASENACK, H., CORDEIRO, J.L.P. \& HOFMANN, G.S. 2003. O clima da RPPN Sesc Pantanal. UFRGS, Porto Alegre.

HECKMAN, C.W. 1998. The Pantanal of Poconé. Biota and ecology in the northern section of the world's largest pristine wetland. Academic Publishers, Kluwer, Dordrecht.

HOFFMAN, R.L., GOLOVATCH, S.I., ADIS, J. \& DE MORAIS, J.W. 2002. Diplopoda. In Amazonian Arachnida and Myriapoda (J. Adis, ed.). Pensoft Plubishers, Sofia, p. 505-534.

JUNK, W.J. 1993. Wetlands of tropical South America. In Wetlands of the world, inventory and management (D. Whigham, S. Hejny \& D. Dykyjova, eds.) W. Junk Publishers, Dordrecht, p. 679-739.

JUNK, W.J. \& NUNES-DA-CUNHA, C. 2005. Pantanal: A large South American wetland at a crossroads. Ecol. Eng. 24:391-401. 10.1016/j. ecoleng.2004.11.012

JUNK, W.J., NUNES-DA-CUNHA, C., WANTZEN, K.M., PETERMANN, P., STRÜSSMANN, C., MARQUES, M.I. \& ADIS, J. 2006. Biodiversity and its conservation in the Pantanal of Mato Grosso, Brazil. Aquat. Sci. 68:278-309. 10.1007/s00027-006-0851-4

JUNK, W.J., PIEDADE, M.T.F., LOURIVAL, R., WITTMANN, F., KANDUS, P., LACERDA, L.D., BOZELLI, R.L., ESTEVES, F.A., NUNESDA-CUNHA, C., MALTCHIK, L., SCHÖNGART, J., SCHAEFFERNOVELLI, Y., AGOSTINHO, A.A., NOBREGA R.L.B. \& CAMARGO, E. 2015. Classificação e delineamento das áreas úmidas brasileiras e de seus macrohabitats. In Definição e classificação das áreas úmidas (AUs) brasileiras, base científica para uma nova política de proteção e manejo sustentável (C. Nunes-da-Cunha, M.T.F. Piedade \& W.J. Junk, eds.). INCTINAU - EdUFMT, Cuiabá, p. 13-76.

LOPES, A., DE PAULA, J.D.A., MARDEGAN, S.F., HAMADA, N. \& PIEDADE, M.T.F. 2011. Influência do habitat na estrutura da comunidade de macroinvertebrados aquáticos associados às raízes de Eichhornia crassipes na região do Lago Catalão, Amazonas, Brasil. Acta Amaz. 41(4):493-502. 10.1590/S0044-59672011000400007

MACHADO, M.P., PIRES, L.R., SILVA, L.T.P., RIGUETE, J.R. \& SILVA, A.G. 2012. Análise de um gradiente fitofisionômico em área de influência de inundação periódica no Pantanal de Poconé, Mato Grosso, Brasil. Natureza On Line 10(2):65-70.

MARQUES, M.I., ADIS, J., BATTIROLA, L.D., SANTOS, G.B. \& CASTILHO, A.C.C. 2011. Arthropods associated with a forest of Attalea phalerata Mart. (Arecaceae) palm three in the northern Pantanal. In The Pantanal: Ecology, biodiversity and sustainable management of a large neotropical seasonal wetland (W.J. Junk, C.J. Da Silva, C. Nunes-da-Cunha \& K.M. Wantzen, eds.). Pensoft Publishers, Sofia, p. 431-468.

MARQUES, M.I., SANTOS, G.B. \& BATTIROLA, L.D. 2014. Cerambycidae (Insecta, Coleoptera) associados à Vochysia divergens Pohl (Vochysiaceae) na região norte do Pantanal de Mato Grosso, Brasil. EntomoBrasilis 7(2):159-160. 10.12741/ebrasilis.v7i2.317 
MEURER, E. 2015. Análise do efeito da inundação e estrutura da vegetação sobre a riqueza e distribuição da assembleia de formigas edáficas, estudo comparativo entre áreas inundáveis e não inundáveis na região norte do Pantanal. Tese de doutorado, Universidade Federal de Mato Grosso, Mato Grosso.

MEURER, E., BATTIROLA, L.D., DELABIE, J.H.C. \& MARQUES, M.I. 2015. Influence of the vegetation mosaic on ant (Formicidae: Hymenoptera) distributions in the northern Brazilian Pantanal. Sociobiology 62(3):382-388. 10.13102/sociobiology.v62i3.359

MINELLI, A. \& GOLOVATCH, S.I. 2013. Myriapods. In Encyclopedia of Biodiversity (S.A. Levin ed.). Waltham, Academic Press, p. 421-432.

MIRANDA, T.A., SANTANNA, A.D.S., VARGAS, A.B. \& ALMEIDA, F.S. 2013. Aspectos estruturais do ambiente e seus efeitos nas assembleias de formigas em ambientes de floresta e bosque. Cadernos UniFOA 21:63-72.

NORONHA, J.C., BATTIROLA, L.D., CHAGAS-JR, A., MIRANDA, R., CARPENEDO, R.S. \& RODRIGUES, D.J. 2015. Predation of bat (Molossus molossus: Molossidae) by the centipede Scolopendra viridicornis (Scolopendridae) in Southern Amazonia. Acta Amaz. 45:333-336. http:// dx.doi.org/10.1590/1809-4392201404083

NUNES-DA-CUNHA, C. \& JUNK, W.J. 2011. A preliminary classification of habitats of the Pantanal of Mato Grosso and Mato Grosso do Sul, and its relation to national and international wetland classification systems. In The Pantanal, Ecology, biodiversity and sustainable management of a large Neotropical seasonal wetland (W.J. Junk, C.J. Silva, C. Nunes-da-Cunha, \& K.M. Wantzen, eds.). Pensoft Publishers, Sofia, p. 127-141.

NUNES-DA-CUNHA, C. \& JUNK, W.J. 2015. A classificação dos macrohabitats do Pantanal Matogrossense. In Classificação e delineamento das áreas úmidas brasileiras, e de seus macrohabitats (C. Nunes-da-Cunha, M.T.F. Piedade \& W.J. Junk eds.). EdUFMT, Cuiabá, p. 77-122.

NUNES-DA-CUNHA, C., JUNK, W.J. \& LEITÃO, H.F. 2007. Woody vegetation in the Pantanal of Mato Grosso, Brazil, a preliminary typology. Amazoniana 19(3):159-184.

OKSANEN, J., BLANCHET, F.G., FRIENDLY, M., KINDT, R., LEGENDRE, P., MCGLINN, D., MINCHIN, P.R., O'HARA, R.B., SIMPSON, G.L., SOLYMOS, P., STEVENS, M.H.H., SZOECS, E. \& WAGNER, H. 2017. Vegan: Community Ecology Package. R package version 2.4-0. https:// CRAN.R-project.org/package $=$ vegan [Accessed 05/09/2017].

OLIVEIRA-FILHO, A.T.D. 1992. The vegetation of Brazilian 'murundus'-the island-effect on the plant community. J. Trop. Ecol. 8(4):465-486. http:// www.jstor.org/stable/2559761

PEREIRA, L.A., ULIANA, M. \& MINELLI, A. 2007. Geophilomorph centipedes (Chilopoda) from termite mounds in the northern Pantanal wetland of Mato Grosso, Brazil. Stud. Neotrop. Fauna E. 42:(1)33-48. $10.1080 / 01650520600915613$

PINHEIRO, T.G., MARQUES, M.I. \& BATTIROLA, L.D. 2009. Life cycle of Poratia salvator Sierwald; Golovatch, 2000 (Diplopoda, Polydesmida, Pyrgodesmidae). Zoologia 26:658-662. 10.1590/S198446702009000400010
PINHEIRO, T.G, BATTIROLA, L.D. \& MARQUES, M.I. 2011. Fertility tables of two populations of the parthenogenetic species Poratia salvator (Diplopoda, Polydesmida, Pyrgodesmidae). Braz. J. Biol. 71:501-510. 10.1590/S1519-69842011000300021

R CORE TEAM 2017. R: A language and environment for statistical computing. R Foundation for Statistical Computing, Vienna, Austria. URL https:// www.R-project.org/ [Accessed 04/09/2017].

RADAMBRASIL 1982. Departamento de Produção Mineral. Projeto Radambrasil. Levantamento de Recursos Naturais. Folha Cuiabá (SD-21). Rio de Janeiro.

REBELLATO, L. \& NUNES-DA-CUNHA, C. 2005. Efeito do "fluxo sazonal mínimo da inundação" sobre a composição e estrutura de um campo inundável no Pantanal de Poconé, MT, Brasil. Acta Bot. Bras. 19:789-799. 10.1590/S0102-33062005000400015

SANTOS, G.B., MARQUES, M.I., ADIS, J. \& MUSIS, C.R. 2003. Arthropods associated with the canopy of the palm Attalea phalerata Mart. (Arecaceae), in the Pantanal of Poconé, Mato Grosso, Brazil. Rev. Bras. Entomol. 47(2): 211-224. 10.1590/S0085-56262003000200010

SANTOS, S.A., POTT, A., RODRIGUES, C.A.C., CARDOSO, E.L., COMASTRI FILHO, J.Á. \& CRISPIM, S.M.A. 2012. Pastagem nativa. In Gado de Corte no Pantanal (E.L. Cardoso, ed.) Embrapa, Brasília, p. 93-132.

SANTOS-SILVA, L., PINHEIRO. T.G., MARQUES, M.I. \& BATTIROLA, L.D. Phenology of Promestosoma boggianii (Diplopoda, Polydesmida, Paradoxosomatidae) in a Neotropical floodplain. Zoologia. 35:e14762. 10.3897/zoologia.35.e14762

SIGNOR, C.A., FERNANDES, I.M. \& PENHA, J. 2010. O Pantanal e o sistema de pesquisa. In Biodiversidade no Pantanal de Poconé (I.M. Fernandes, C.A. Signor \& J. Penha, eds.). Attema Editora, Manaus, p. 13-23.

SILVA, M.P.D., MAURO, R., MOURÃO G. \& COUTINHO, M. 2000. Distribuição e quantificação de classes de vegetação do Pantanal através de levantamento aéreo. Rev. Bras. Bot. 23(2):143-152. 10.1590/S010084042000000200004

TEWS, J., BROSE, U., GRIMM, V., TIELBÖRGER, K., WICHMANN, M.C., SCHWAGER, M. \& JETSCH, F. 2004. Animal species diversity driven by habitat heterogeneity/diversity: The importance of keystone structures. J. Biogeogr. 31:79-92. 10.1046/j.0305-0270.2003.00994.x

WANTZEN, K.M., MARCHESE, M.R., MARQUES, M.I. \& BATTIROLA, L.D. 2016. Invertebrates in Neotropical Floodplains. In Invertebrates in Freshwater Wetlands (D. Batzer \& D. Boix, eds.). Springer International Publishing, Switzerland, p. 493-524.

YAMAZAKI, L., MARQUES, M.I., BRESCOVIT, A.D. \& BATTIROLA, L.D. 2015. Tityus paraguayensis (Scorpiones: Buthidae) em copas de Callisthene fasciculata (Vochysiaceae) no Pantanal de Mato Grosso (Brasil). Acta Biol. Par. 44(3-4):153-158. 10.5380/abpr.v44i1-4.44122
Received: $15 / 01 / 2018$

Revised: $15 / 03 / 2018$

Accepted: 20/03/2018

Published online: 23/04/2018 